\title{
THE SUSTAINABILITY OF BAMBOO MATERIALS IN THE BUMI PEMUDA RAHAYU BAMBOO HALL BUILDING
}

\author{
${ }^{1}$ Gallus Presiden Dewagana, ${ }^{2}$ Dr. Ir. Kamal A. Arif, M.Eng \\ ${ }^{1}$ Student in the Bachelor's (S-1) Study Program in Architecture \\ at Parahyangan Catholic University \\ ${ }^{2}$ Senior lecturer in the Bachelor's (S-1) Study Program in Architecture \\ at Parahyangan Catholic University
}

\begin{abstract}
The issue of global warming strongly encourages architects to use sustainable materials to preserve nature. Bamboo material is an ecological and sustainable material. Bamboo is also predicted as a future material. The strengths and advantages of bamboo are very likely to be used as a building construction material. Unfortunately, it is not uncommon for bamboo material to be used inappropriately so that it does not optimize the ecological and sustainable properties of bamboo. The object of study chosen was the Bumi Pemuda Rahayu bamboo hall. This object is close to the concept of sustainability as seen from the function of the building, which is a co-creating space that prioritizes sustainability-related activities.

This research uses qualitative-quantitative methods that will compare the theory regarding the concept of sustainability of materials related to the building material life cycle with the data obtained. The concept will be divided into three aspects, namely design aspects, construction aspects, and maintenance and renovation aspects. These three aspects can be examined by knowing the object data related to these aspects. The results of the study will answer whether the use of bamboo material in the object of study is in accordance with the concept of sustainability of the bamboo material.

The analysis of the design stage pays attention to material selection, material preservation, how to optimize the age of bamboo and the selection of a structural system. The construction stage is analyzed by considering the type of connection used. The maintenance and renovation phases are analyzed by paying attention to how to renovate the bamboo structure and post-construction maintenance of the building.

This building is appropriate in choosing the type of material, applying preservation of bamboo materials, and successfully preventing bamboo from environmental influences in order to reach its optimal age. In terms of structural system selection, this building is also appropriate by applying the arc rod structural system. Bolted joints are appropriate for complex structural systems, it's just that there must be special treatment at the base of the arc structure that receives the greatest load due to cracks. Renovation and maintenance aspects must be considered again because this building will have difficulty if you have to do renovations, especially on the arc structure. Maintenance that is rarely performed can also reduce the life of the building.
\end{abstract}

Key Words: bamboo, sustainable materials, Bumi Pemuda Rahayu

\section{KEBERLANJUTAN MATERIAL BAMBU PADA BANGUNAN AULA BAMBU BUMI PEMUDA RAHAYU}

\author{
${ }^{1}$ Gallus Presiden Dewagana, ${ }^{2}$ Dr. Ir. Kamal A. Arif, M.Eng \\ ${ }^{1}$ Mahasiswi S1 Program Studi Arsitektur Universitas Katolik Parahyangan \\ ${ }^{2}$ Dosen Pembimbing S1 Program Studi Arsitektur Universitas Katolik Parahyangan
}

\begin{abstract}
Abstrak - Isu pemanasan global sangat mendorong arsitek untuk menggunakan material yang berkelanjutan untuk menjaga kelestarian alam. Material bambu adalah material ekologis dan berkelanjutan. Bambu juga digadanggadang sebagai material masa depan. Kekuatan dan kelebihan yang dimiliki bambu sangat mungkin untuk
\end{abstract}

\footnotetext{
${ }^{1}$ Corresponding Author: gallus.presiden@gmail.com
} 
dimanfaatkan sebagai material konstruksi bangunan. Sayangnya, tidak jarang material bambu digunakan dengan tidak tepat sehingga tidak mengoptimalkan sifat ekologis dan berkelanjutan dari bambu. Objek studi yang dipilih adalah aula bambu Bumi Pemuda Rahayu. Objek tersebut dekat dengan konsep keberlanjutan dilihat dari fungsi bangunan tersebut yang merupakan co-creating space yang mengedepankan kegiatan-kegiatan terkait sustainability.

Penelitian menggunakan metode kualitatif-kuantitatif yang akan membandingkan teori mengenai konsep keberlanjutan material terkait building material life cycle dengan data yang didapat. Konsep tersebut akan dibedah menjadi tiga aspek, yaitu aspek desain, aspek konstruksi, dan aspek perawatan dan renovasi. Ketiga aspek tersebut dapat ditelaah dengan mengetahui data objek terkait aspek tersebut. Hasil penelitian akan menjawab apakah penggunaan material bambu pada objek studi sudah sesuai dengan konsep keberlanjutan material bambu.

Analisis tahap desain memperhatikan pemilihan material, preservasi material, cara mengoptimalkan usia bambu dan pemilihan sistem struktur. Tahap konstruksi dianalisis dengan memperhatikan jenis sambungan yang digunakan. Tahap perawatan dan renovasi dianalisis dengan memperhatikan cara merenovasi struktur bambu dan perawatan pasca konstruksi pada bangunan.

Bangunan ini tepat dalam memilih jenis material, penerapan preservasi material bambu, dan berhasil menghindarkan bambu dari pengaruh lingkungan agar mencapai usia optimal. Secara pemilihan sistem struktur, bangunan ini juga tepat dengan menerapkan sistem struktur rangka batang busur. Sambungan baut tepat digunakan untuk sistem struktur yang kompleks, hanya saja harus ada perlakuan khusus pada bagian pangkal struktur busur yang menerima beban paling besar karena terdapat retak. Aspek renovasi dan perawatan harus diperhatikan lagi karena bangunan ini akan kesulitan jika harus melakukan renovasi, terutama pada bagian struktur busur. Perawatan yang jarang dilakukan juga dapat mengurangi usia bangunan.

Kata Kunci: bambu, material berkelanjutan, Bumi Pemuda Rahayu

\section{PENDAHULUAN}

Pemanasan global dan perubahan iklim menjadi isu yang banyak disoroti oleh banyak pihak dalam beberapa tahun terakhir. Arsitek di seluruh dunia juga mulai sering membahas topik tersebut. Menurut Berge (2009), bidang industri bangunan adalah pengguna bahan baku terbesar di dunia setelah industri makanan².

Pemilihan material merupakan aspek yang krusial dalam usaha mengurangi dampak buruk pada lingkungan. Material bangunan terbarukan seperti kayu dan bambu juga bisa habis ketika manajemen panennya tidak tepat. Saat ini bambu digadang-gadang sebagai material masa depan. Menurut Efa (2017), bambu sebagai material memiliki keunggulan dan potensi menjanjikan di berbagai aspek, termasuk aspek terhadap keramahan lingkungan . Bambu dianggap telah selaras dengan kriteria material ekologis dalam upaya pemenuhan aspek konsep green building.

Material bambu dapat digunakan hampir dalam setiap elemen bangunan, mulai dari lantai, dinding, sampai atap. Tetapi pada kenyataannya, material bambu lebih sering digunakan sebagai material pelengkap arsitektural seperti fasad atau ornamen. Meskipun demikian, kekuatan material bambu dapat dimanfaatkan untuk elemen struktural bangunan. Bambu sebagai material ekologis sudah seharusnya diperlakukan dengan ekologis dan berkelanjutan. Siklus material bambu dikedepankan agar penggunaan bambu sebagai material ekologis lebih optimal. Bambu dengan sifat ekologisnya akan tidak berarti jika bangunan yang dibuat tidak meninjau aspek keberlanjutan, seperti tidak memperhatikan siklus hidup bambu, tidak melakukan preservasi untuk memperpanjang usia bambu, dan tidak mendesain untuk memaksimalkan usia bambu.

Metode yang digunakan dalam skripsi ini adalah metoda kualitatif-kuantitatif. Data objek studi yang didapatkan akan dianalisis dengan cara dibandingkan dengan landasan teori yang didapat dari studi literatur.

\footnotetext{
${ }^{2}$ Berge, B. 2009. The Ecology of Building Materials Second Edition. Oxford: Elsevier.
} 
Penulis berharap skripsi ini dapat menambah referensi masyarakat mengenai penggunaan material bambu yang dapat digunakan secara lebih berkelanjutan. Mengingat kebutuhan membangun akan selalu ada, dibutuhkan inovasi-inovasi dalam hal penggunaan material terbarukan untuk menjaga alam tetap lestari.

Objek penelitian yang diambil adalah aula bambu Bumi Pemuda Rahayu. Bangunan ini terletak di Desa Banjarharjo II, Muntuk, Dlingo, Kabupaten Bantul, Daerah Istimewa Yogyakarta. Proses pembangunan dimulai sejak 2012 dan selesai pada 2015. Bumi Pemuda Rahayu adalah tempat belajar dan berkegiatan kreatif yang dapat digunakan oleh warga sekitar dan juga oleh masyarakat umum. Kegiatan yang sering dilakukan di tempat ini seperti belajar arsitektur terkait bangunan Bumi Pemuda Rahayu, belajar mengenai ekologi, workshop kesenian, dan residensi seniman.

Bumi Pemuda Rahayu diprakarsai oleh Marco Kusumawijaya bersama dengan Rujak Centre for Urban Studies (RCUS). Arsitek utama bangunan ini adalah Andesha Hermintomo, sedangkan desain struktur aula bambu dirancang oleh Effan Adhiwira dari EFF Studio. Pembangunan aula bambu dikerjakan oleh Yuli Kusworo bersama dengan Arkom Jogja.

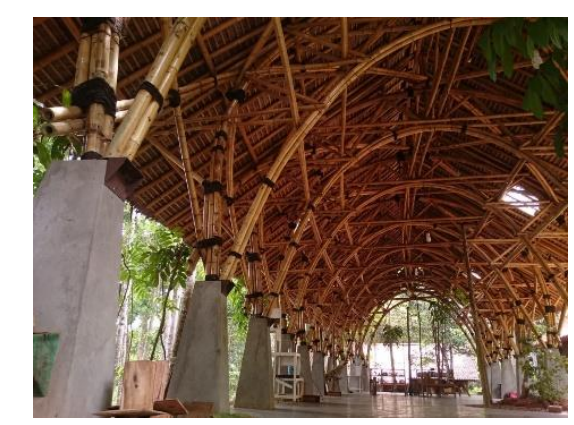

Gambar 1. Suasana ruang dalam aula bambu

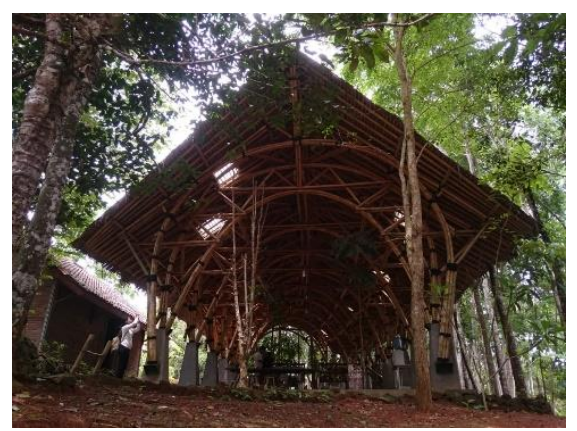

Gambar 2. Tampak belakang aula bambu

Bumi Pemuda Rahayu sebagai tempat publik menerapkan konsep kelestarian. Hal ini disampaikan oleh Andesha Hermintomo sebagai arsitek yang merancang master plan Bumi Pemuda Rahayu. Konsep tersebut terwujud dari perletakan massa yang mempertimbangkan kontur dan vegetasi eksisting dan pemilihan material yang mudah didapat seperti bambu, batu bata, dan kayu. Selain itu, bangunan ini dirancang seterbuka mungkin dengan lingkungan sekitar, hal ini terwujud dengan tidak adanya pagar di area bangunan ini sehingga warga sekitar dapat mengakses bangunan ini dengan mudah dan tidak merasa ada batas.

Konsep arsitektur yang lestari di Bumi Pemuda Rahayu perlu ditelaah lagi, terutama pada bangunan aula bambu. Bambu sebagai material alam sering kali digunakan tidak sesuai dengan building material life cycle-nya. Proses panen bambu yang tidak memperhatikan siklus hidup bambu membuat ketersediaan bambu terus berkurang tanpa dapat beregenerasi. Bambu yang telah ditebang harus dilakukan preservasi agar bambu lebih awet dan kuat. Desain bangunan bambu yang tidak memperhatikan ketahanan bambu juga akan membuat usia bangunan tidak optimal

Dengan konsep yang dibawa, perlu ditelaah apakah bangunan yang dirancang dan digunakan menggunakan konsep yang sama atau sebaliknya. Memilih material bambu sebagai material utama harus diikuti oleh pemahaman bahwa bambu harus diperlakukan sesuai dengan karakternya agar dapat memenuhi perannya sebagai material ekologis. Bambu yang dirancang tanpa memperhatikan karakternya justru akan membuat bambu menjadi material yang lemah dan mudah rusak.

Penelitian ini akan menjawab pertanyaan-pertanyaan terkait penerapan konsep keberlanjutan material bambu pada bangunan aula bambu Bumi Pemuda Rahayu. Sebagai 
tempat yang membawa nilai kelestarian dan keberlanjutan, konsep keberlanjutan material bambu pada bangunan aula bambu sudah sepatutnya diterapkan.

Penelitian ini akan membahas konsep keberlanjutan material bambu melalui tiga bagian, aspek desain, aspek konstruksi, dan aspek renovasi dan perawatan. Ketiga bagian tersebut memiliki ruang lingkup masing-masing. Aspek desain akan fokus pada pemilihan material, preservasi material, upaya desain untuk mengoptimalkan usia bambu dan pemilihan sistem struktur. Aspek konstruksi akan fokus pemilihan jenis sambungan. Aspek renovasi dan perawatan fokus pada cara renovasi dan perawatan material bambu.

Mengetahui sejauh mana bangunan ini menerapkan konsep keberlanjutan material bambu adalah tujuan dari penelitian ini. Masing-masing bagian akan menjabarkan bagaimana bangunan aula bambu Bumi Pemuda Rahayu menerapkan konsep keberlanjutan material bambu. Dengan mengetahui hal tersebut, diharap penelitian ini dapat memberi wawasan mengenai material bambu sebagai material bangunan. Penelitian ini juga diharap dapat mendorong pembangunan yang bersifat ramah lingkungan dengan penggunaan material terbarukan seperti bambu.

\section{KAJIAN TEORI}

Keberlanjutan pada arsitektur lekat kaitannya dengan konsep green building. Green building didefinisikan sebagai sesuatu yang merupakan hasil yang dapat didaur ulang atau bangunan yang sedikit menimbulkan dampak negatif terhadap lingkungannya (McLennan, 2004). Mengingat dampak buruk yang dihasilkan oleh industri bangunan, sangat penting untuk meninjau ulang pendekatan dalam merancang agar semakin dekat dengan konsep green building.

Pemilihan dan perlakuan pada material menjadi salah satu aspek yang penting. Hal ini dapat dilihat dari peran material tersebut dalam tahapan pembangunan yang disebut sebagai building material life cycle, yaitu: pre-building, building operation, dan post-building. Tahapan tersebut sebaiknya dilaksanakan secara berkesinambungan sehingga terwujud bangunan ramah lingkungan

Tahap pre-building merupakan tahap paling awal dalam siklus material bangunan. Aspek yang terkait pada tahap ini adalah ekstraksi material, proses menjadikan material, kemasan material, dan sistem pengiriman material. Pemilihan material lokal hasil olahan atau yang mudah diperoleh di sekitar kawasan proyek menjadi langkah awal. Selain itu juga dapat menggunakan material yang bahan baku dan produksinya ramah lingkungan.

Tahap building operation memperhatikan aspek konstruksi dan sistem struktur, instalasi, operasional, dan maintenance. Usia yang panjang menjadi salah satu tolok ukur pada tahap ini. Pemilihan metode konstruksi, detail konstruksi, proses intalasi, hingga proses renovasi dan perawatan harus dilakukan untuk membuat material berusia panjang.

Tahap terakhir dari siklus material bangunan yaitu tahap post-building fokus pada manajemen material untuk dapat didaur ulang atau digunakan kembali. Metode renovasi juga terkait dengan rancangan yang dihasilkan. Dengan penempatan yang tepat, material alam yang telah mencapai usia maksimalnya dapat dengan mudah diganti dengan material baru.

Konsep keberlanjutan material dengan memperhatikan building material life cycle seperti yang disebutkan di atas merupakan konsep keberlanjutan material secara umum. Material bambu memiliki pengertian keberlanjutan yang spesifik. Material bambu dianggap

\footnotetext{
${ }^{3}$ Suriani, E. 2017. Bambu Sebagai Alternatif Penerapan Material Ekologis: Potensi dan Tantangannya. EMARA Indonesian Journal of Architecture Vol. 31 No. 1, 41.
} 
menjadi material yang memenuhi konsep keberlanjutan jika dirancang sesuai dengan karakternya, baik karakter mekanis maupun karakter alami.

Bambu secara botanis termasuk tanaman rumput dan tergolong pada famili Graminae. Berbeda dengan jenis rumput lainnya, bambu adalah satu-satunya jenis rumput yang dapat melakukan diversifikasi dan adaptasi di dalam habitat hutan. Tanaman bambu tidak mengenal perkembangan gamang, pertumbuhan bambu selayaknya rumput adalah tumbuh ke atas. Bambu berkembang biak dengan akar rimpang yang berfungsi sekaligus untuk mengikat batang bambu pada tanah ${ }^{4}$.

Bambu merupakan tanaman yang mudah ditemui di Indonesia, serta mudah dan cepat tumbuh. Beberapa jenis bambu dapat tumbuh sampai $120 \mathrm{~cm}$ per hari ${ }^{5}$. Bambu dengan usia 46 tahun dapat digunakan untuk struktur dan konstruksi sebuah bangunan, lebih cepat daripada kayu yang membutuhkan 10-30 tahun untuk memenuhi syarat kekuatan sebagai material struktur dan konstruksi.

Bambu memiliki kelebihan seperti bobotnya yang ringan sehingga cocok digunakan sebagai material konstruksi bangunan tahan gempa. Selain itu masa tumbuh bambu yang tergolong singkat juga menjadi kelebihan material ini. Secara kekuatan struktur, bambu lebih kuat terhadap gaya tarik, walau begitu, dengan penerapan yang tepat, bambu tetap dapat menahan gaya tekan. Sedangkan kekurangan bambu adalah sifat materialnya yang bergantung pada jenis, tempat tumbuh, dan tingkat kelembapan. Bambu juga rentan terhadap air hujan dan sinar matahari sehingga membutuhkan penanganan khusus dalam desain.

Jenis bambu yang sering digunakan sebagai material bangunan adalah bambu tali dan bambu petung. Bambu tali atau apus adalah jenis bambu yang sangat lentur. Bambu tali memiliki jarak antar ruas sampai $65 \mathrm{~cm}$ dan dengan diameter $40-80 \mathrm{~mm}$. Panjang bambu tali berkisar antara 6 meter sampai 13 meter. Sedangkan bambu petung adalah bambu yang sangat kuat namun kurang lentur karena dinding bambu yang cukup tebal. Diameter bambu petung dapat mencapai $80-130 \mathrm{~mm}$ dan panjang bambu berkisar antara 10 meter sampai 20 meter.

Sebagai material konstruksi, perlu dipahami sifat mekanika bambu sehingga dapat menjadi titik berangkat dalam mendesain struktur. Bambu yang digunakan sebagai material konstruksi merupakan bambu kering dengan kadar air kesetimbangan 12\% pada kelembapan udara rata-rata iklim tropis yaitu $70 \%{ }^{6}$.

Sifat mekanika bambu tergantung pada:

1. Jenis bambu.

2. Umur pada saat ditebang.

3. Kelembapan pada batang.

4. Bagian batang bambu yang digunakan (kaki, pertengahan, atau kepala).

5. Letak dan jarak ruas.

\footnotetext{
${ }^{4}$ Frick, H. 2004. Ilmu Konstruksi Bangunan Bambu. Yogyakarta: Kanisius.

${ }^{5}$ Network, C. A. 2013. Bamboo Construction Source Book.

${ }^{6}$ Frick, H. 2004. Ilmu Konstruksi Bangunan Bambu. Yogyakarta: Kanisius.
} 
Tabel 1 Sifat Mekanika Bambu

\begin{tabular}{|l|l|}
\hline \multicolumn{1}{|c|}{ Sifat Mekanika } & \multicolumn{1}{c|}{ Nilai } \\
\hline 1. Berat Jenis & $700 \mathrm{~kg} / \mathrm{m}^{3}$ \\
\hline 2. Kuat Tarik & $29.4 \mathrm{~N} / \mathrm{mm}^{2}$ \\
\hline 3. Kuat Tekan & $7.85 \mathrm{~N} / \mathrm{mm}^{2}$ \\
\hline 4. Kuat Geser & $2.45 \mathrm{~N} / \mathrm{mm}^{2}$ \\
\hline 5. Kuat Lentur & $9.80 \mathrm{~N} / \mathrm{mm}^{2}$ \\
\hline 6. Modul Elastis & $20 \mathrm{kN} / \mathrm{mm}^{2}$ \\
\hline
\end{tabular}

Peningkatan ketahanan bambu dapat dilakukan dengan memperhatikan proses panen, pengeringan, penyimpanan, hingga pengawetan. Proses tersebut menjadi penting untuk meningkatkan usia bambu ketika dipakai sebagai material konstruksi. Bambu sebagai bahan bangunan sebaiknya dipanen pada usia 3-6 tahun. Pada umur itu, bambu memiliki mutu dan kekuatan yang paling tinggi. Batang bambu dipotong sekitar $15-30 \mathrm{~cm}$ di atas tanah, langsung pada bagian atas ruas agar air tidak berkumpul pada tinggi ruas yang terbuka.

Proses pengeringan bambu dilakukan untuk mengurangi kadar air dan kanji pada batang. Terdapat beberapa metode pengeringan bambu seperti pengeringan pada semak, air drying, dan microwave drying. Teknik pengawetan bambu dapat dibagi menjadi dua metode, yaitu metode non-kimia dan metode kimia. Metode non-kimia dilakukan dengan tidak menggunakan bahan-bahan kimia dan memanfaatkan unsur alam seperti air, sungai, dan pengasapan. Sedangkan metode kimia umumnya menggunakan menggunakan pengawet seperti Copper-Chrome-Arsenic (CCA) atau Copper-Chrome-Boron (CCB).

Bambu memiliki karakter alami seperti tidak tahan air hujan dan sinar matahari. Selain itu bambu juga merupakan material yang mudah terbakar sehingga harus dijauhkan dari sumber api. Untuk mempertahankan kekuatannya, bambu harus dijauhkan dari kontak langsung dengan tanah. Tanah mengandung air dan lembap sehingga dapat merusak batang bambu. Bangunan dari bambu juga dapat dibuat dengan teritis lebar sehingga melindungi bagianbagian bangunan dari paparan air hujan dan sinar matahari.

Bambu memiliki tingkat kesulitan yang berbeda dengan kayu. Bentuk silindris pada bambu membuat teknik konstruksi yang digunakan berbeda antara bambu dengan kayu. Spesifikasi bambu terkait diameter dan panjang batang bambu serta sifat batangnya yang berserat membuat bambu memiliki teknik tersendiri dalam mengolahnya menjadi elemen struktur maupun dalam membuat sambungan.

Desain bambu modern banyak menggunakan sambungan seperti baut besi atau plat baja. Hal ini diikuti oleh perkembangan teknologi konstruksi yang semakin maju, hanya saja penggunaan sambungan modern masih dibatasi oleh pengetahuan dan keterampilan tukang. Selama ini jenis sambungan konvensional lebih dikenal oleh masyarakat secara umum. 


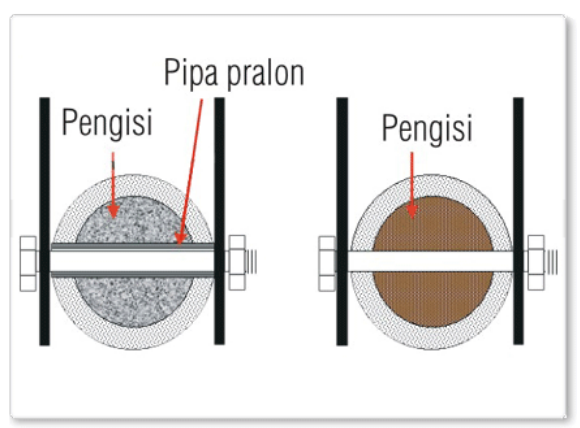

Gambar 3. Sambungan bambu menggunakan baut

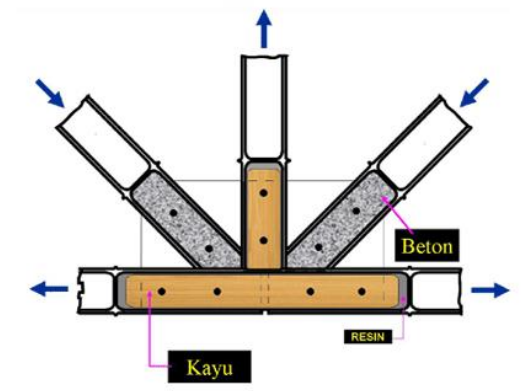

Gambar 4. Sambungan bambu menggunakan beton Sumber: moriscobamboo.com

Sumber: moriscobamboo.com

Perawatan bambu merupakan proses menjaga kualitas bambu pasca-konstruksi. Walau telah diawetkan, perawatan bambu merupakan hal yang penting agar penggunaan bambu optimal. Perawatan yang dilakukan adalah menjaga bambu agar tidak basah karena ketika basah bambu akan lapuk dan mudah ditumbuhi jamur. Perawatan pasca-konstruksi dibedakan menjadi dua jenis yaitu perawatan secara tradisional dan kimiawi. Perawatan secara tradisional relatif lebih murah dan aman dibanding perawatan secara kimiawi.

Bangunan aula bambu Bumi Pemuda Rahayu menggunakan struktur rangka batang busur. Struktur busur adalah sistem struktur berupa elemen garis yang berbentuk lengkung dengan garis yang tidak terputus ${ }^{7}$. Gaya internal pada struktur busur disalurkan secara menyeluruh melalui batang busur dan tidak terfokus pada satu titik. Struktur busur termasuk dalam struktur funicular atau struktur yang hanya terbebani oleh gaya tekan atau tarik saja.

Struktur busur memiliki penyaluran beban yang berbeda dengan struktur lainnya. Penyaluran beban pada struktur busur terjadi sepanjang lengkungan busur. Pada struktur busur, terdapat beban vertikal yang terjadi karena gaya gravitasi dan beban horizontal keluar yang terjadi karena kecenderungan struktur busur untuk menjadi lurus jika terbebani. Seperti struktur pada umumnya, beban lateral menjadi pertimbangan dalam setiap desain struktur. Beban lateral merupakan beban yang diakibatkan oleh angin atau gempa bumi. Selain itu, gaya internal pada struktur busur juga memberikan beban lateral.

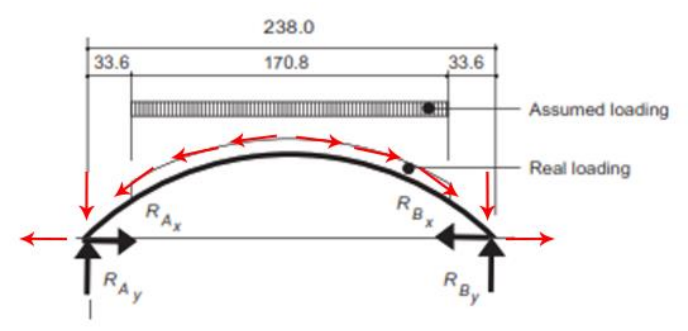

Gambar 5. Penyaluran beban pada struktur busur Sumber: (Schodek, 2014)

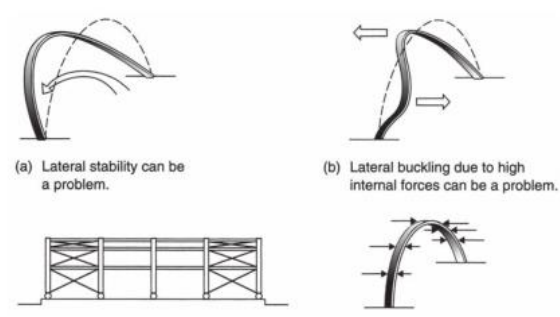

Gambar 6. Perilaku struktur busur terhadap gaya lateral

Sumber: (Schodek, 2014)

${ }^{7}$ (Schueller, 1996) 
Gaya tekan dan gaya tarik bekerja dalam masing-masing batang untuk saling menyeimbangkan. Adakalanya batang tarik menahan gaya tekan agar tidak berpindah tempat. Batang tarik berfungsi untuk membuat batang tekan tetap pada tempatnya. Penyaluran gaya dengan batang tekan terjadi dengan batang tepi atas turun akibat beban dan berat sendiri sehingga batang tepi bawah harus mengikat pasangan batang tepi atas untuk menahan pergeseran. Sistem ini juga dapat dibalik menurut gambar di bawah.

Dalam perkembangannya, sistem struktur rangka batang ini dapat dimanfaatkan menurut bentuknya sebagai segitiga (kuda-kuda), dengan bentuk kotak (konstruksi jembatan), dengan tepi atas dan bawah melengkung (konstruksi busur), maupun yang bersudut (konstruksi portal).

Bentuk busur dapat dianggap sebagai bentuk kotak (persegi panjang) yang dilengkungkan. Karena bentuk busur mengakibatkan gaya tarik di bidang tumpuan engsel, dibutuhkan batang tarik di antaranya. Dengan sifat tarik dan tekan yang identik, dapat disimpulkan bahwa batang atas busur akan selalu bersifat tekan dan batang bawah busur bersifat tarik. Sifat tarik dan tekan batang lain akan ditentukan oleh arah batang diagonal.

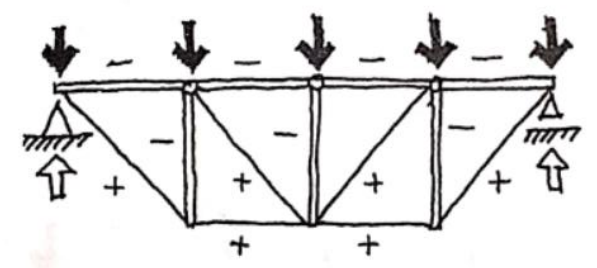

Gambar 7. Rangka batang persegi panjang dengan arah diagonal ke atas Sumber: (Frick, 2007)

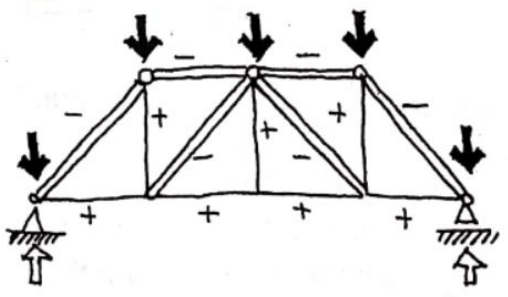

Gambar 8. Rangka batang persegi panjang dengan arah diagonal ke bawah Sumber: (Frick, 2007)

\section{METODE PENELITIAN}

Penelitian dilakukan dengan metoda kualitatif kuantitatif dengan membandingkan data objek studi berupa gambar kerja, hasil wawancara lisan, foto objek studi dan rekaman data renovasi bangunan. Hasil penelitian merupakan hasil analisis dari studi observasi serta wawancara dengan pihak arsitek yang kemudian dibandingkan dengan studi literatur. Dari hasil analisis tersebut ditarik kesimpulan yang merupakan hasil akhir penelitian.

Data yang digunakan merupakan hasil pengamatan melalui gambar kerja serta pengamatan langsung di lapangan. Selain itu, wawancara juga diterapkan dengan mewawancarai arsitek utama, arsitek struktur bambu, dan pengguna atau pengelola bangunan.

Wawancara diperlukan untuk mendapat penjelasan langsung terkait desain dan metode konstruksi yang tidak dapat dijelaskan melalui gambar. Wawancara akan dilakukan secara daring dengan arsitek atau yang mewakili. Studi pustaka juga dilakukan sebagai data awal yang berfungsi untuk mengetahui hal-hal yang perlu diperhatikan terkait konsep keberlanjutan pada material bambu. Data juga digunakan untuk menganalisis data hasil observasi dan wawancara terkait desain aula bambu Bumi Pemuda Rahayu. 
Data dari hasil observasi dan wawancara lisan akan dibedah menggunakan teori yang didapat dari studi pustaka. Konsep keberlanjutan material bambu terkait building material life cycle pada objek studi dianalisis menggunakan teori mengenai rincian yang terdapat pada building material life cycle. Penarikan kesimpulan merupakan hasil perbandingan antara data observasi dan wawancara dengan teori yang didapatkan. Kesimpulan yang dihasilkan dapat menjawab apakah penggunaan material bambu pada objek studi sesuai dengan konsep keberlanjutan material bambu.

\section{ANALISIS}

Siklus bangunan dimulai dari tahap perancangan atau tahap desain. Pada tahap ini, ada tiga hal yang diperhatikan, yaitu pemilihan material dengan fokus pada sumber material, preservasi material yang fokus pada jenis pengawetan yang digunakan, dan upaya desain untuk menghindarkan bambu dari hujan, sinar matahari langsung, kontak dengan tanah, dan kebakaran agar usia bambu optimal.

Bambu yang digunakan pada bangunan Bumi Pemuda Rahayu adalah bambu apus atau bambu tali (Gigantochloa apus). Pertimbangan utama pemilihan jenis bambu pada bangunan ini adalah faktor biaya. Harga bambu patung di pasaran lebih mahal hingga lima kali lipat dibanding bambu tali. Keterbatasan biaya justru mendorong arsitek untuk dapat memaksimalkan karakter material yang ada. Selain faktor biaya, ketersediaan bambu tali di sekitar tapak juga menjadi pertimbangan sehingga ketika suatu saat dibutuhkan bambu pengganti secara darurat, dapat diambil dari rumpun bambu di sekitar tapak.

Bambu tali adalah jenis bambu dengan jarak antar ruas $65 \mathrm{~cm}$ dan diameter berkisar antara 40 sampai $80 \mathrm{~mm}$ serta panjang batang 6-13 meter. Sifat mekanika bambu tali adalah sebagai berikut:

Tabel 2. Sifat Mekanika Bambu Tali

\begin{tabular}{|l|l|l|}
\hline No. & Sifat Mekanika & Hasil \\
\hline 1. & Kuat tarik & $270,94 \mathrm{MPa}$ \\
\hline 2. & Kuat tekan & $48,97 \mathrm{MPa}$ \\
\hline 3. & Kuat lentur & $70,46 \mathrm{MPa}$ \\
\hline 4. & Kuat geser dengan ruas & $5,14 \mathrm{MPa}$ \\
\hline 5. & Kuat geser tanpa ruas & $4,02 \mathrm{MPa}$ \\
\hline 6. & Kuat tumpu baut & $37,38 \mathrm{MPa}$ \\
\hline 7. & Modulus elastisitas tarik & $18.058 \mathrm{MPa}$ \\
\hline 8. & Modulus elastisitas tekan & $25.852 \mathrm{MPa}$ \\
\hline 9. & Modulus elastisitas lentur & $19.514 \mathrm{MPa}$ \\
\hline
\end{tabular}

Dengan kekuatan tekan dan tarik yang kurang lebih sama dengan bambu betung, bambu tali dapat dikatakan tepat digunakan sebagai material utama struktur bangunan. Sifat lentur yang membedakan keduanya menjadi aspek pembeda yang mempengaruhi bentuk bangunan. Diameter yang jauh setengah lebih kecil, membuat bambu tali yang digunakan untuk struktur harus terdiri lebih dari satu batang untuk mencapai ketebalan yang diinginkan.

Aula bambu di Bumi Pemuda Rahayu menggunakan tiga material utama, beton sebagai pondasi, bambu tali sebagai struktur badan dan atap, dan rumbia sebagai atap. Di sekitar tapak, terdapat banyak pohon bambu, namun bambu yang digunakan berasal dari wilayah Kaliurang, 
Sleman, DIY. Bambu didapat dari Sahabat Bambu, spesialis pengawetan, desain dan konstruksi bambu. Lokasi Sahabat Bambu berada kurang lebih 38,5 kilometer dari tapak.

Walau bambu yang digunakan tidak berasal dari material di sekitar tapak, pengerjaan pembangunan bangunan ini melibatkan warga sekitar sebagai tukang. Dalam proses awal pembangunan, didatangkan tukang bambu dari Bali yang sudah sering bekerja sama dengan Effan Adhiwira di EFF Studio. Tukang bambu dari Bali mengajarkan teknis dan metode membangun bangunan bambu kepada warga sekitar. Setelah proses transfer ilmu selesai, proses pembangunan dilanjutkan oleh warga sekitar sampai dengan selesai.

Bambu yang digunakan pada bangunan ini telah berusia 4 tahun dan telah melalui proses pengeringan dan pengawetan oleh Sahabat Bambu. Pengawetan yang dilakukan adalah dengan metode kimiawi menggunakan bahan pengawet borax dan boric. Penggunaan bahan pengawet ini sering dipakai di tempat pengawetan bambu Sahabat Bambu.

Upaya desain dilakukan oleh perancang untuk mengoptimalkan usia bambu. Usia bambu yang sudah dikeringkan dan diawetkan dapat mencapai 15-20 tahun. Untuk mencapai hal tersebut, bambu harus dihindarkan dari kontak langsung dengan air dan tanah, paparan sinar matahari, dan perlindungan terhadap bahaya kebakaran.

Pemilihan tapak menjadi hal pertama yang harus diperhatikan. Tapak tidak boleh berada di daerah bekas sungai, area yang mudah banjir, atau area tanah urug. Bangunan aula bambu Bumi Pemuda Rahayu sudah tepat dalam pemilihan tapak. Tapak berada di lahan datar dan bukan merupakan tanah urug. Selain itu, lantai kerja juga dinaikan $20 \mathrm{~cm}$ untuk menghindari genangan air masuk ke dalam aula. Kenaikan lantai dibagi menjadi dua bagian dengan masing-masing ketinggian $10 \mathrm{~cm}$. Bagian pertama adalah dengan batu gamping, dan kemudian lantai kerja.

Selain itu, panjang teritis harus dapat melindungi bambu dari terpaan air hujan. Teritis atap pada sisi samping bangunan dapat menahan sudut datang air hujan sampai dengan 40 derajat. Sudut datang air hujan sangat ditentukan oleh kecepatan angin ketika hujan. Menurut data dari BMKG dan Bappeda Provinsi Yogyakarta, kecepatan angin di Kabupaten Bantul berkisar di angka $20 \mathrm{~km} / \mathrm{jam}$. Dengan kecepatan rata-rata tersebut, sudut 40 derajat cukup untuk melindungi bambu dari air hujan.

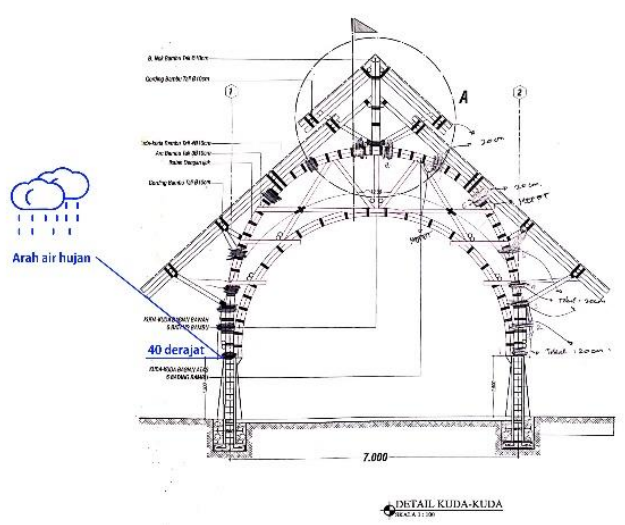

Gambar 9. Arah datang air hujan pada sisi samping bangunan

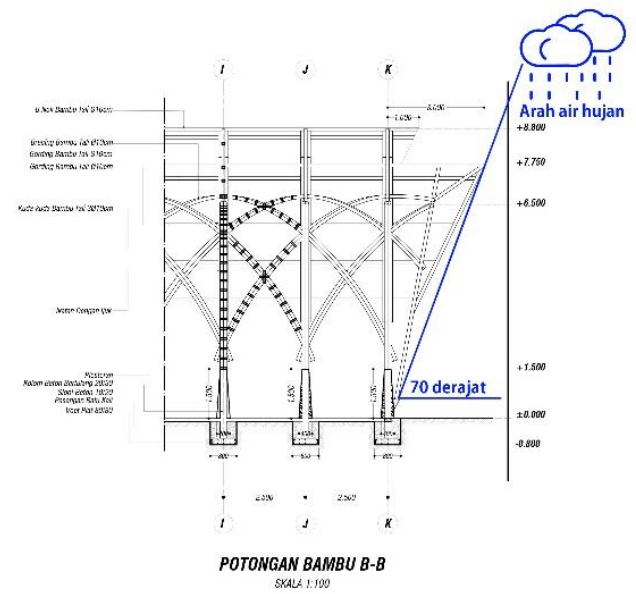

Gambar 10. Arah datang air hujan pada sisi depan dan belakang bangunan

Upaya untuk menghindarkan bambu dari hujan sama seperti upaya menghindarkan bambu dari paparan sinar matahari langsung. Panjang teritis bagian samping dan ketinggian pondasi dapat menghindarkan bambu dari paparan sinar matahari langsung. Sisi samping 
tersebut menghadap timur dan barat sehingga melindungi dari paparan sinar matahari ketika terbit dan tenggelam. Sedangkan sisi depan dan belakang yang menghadap utara dan selatan kurang terlindungi seperti halnya perlindungan terhadap air hujan.

Perlindungan terhadap kebakaran juga dirancang dengan baik. Letak struktur bambu paling rendah berada pada level 1,5 meter sehingga cukup jauh dari area kerja di rentang 0-90 $\mathrm{cm}$. Selain itu, area yang aktivitasnya menggunakan api seperti dapur diletakan di massa yang terpisah dengan massa aula bambu.

Struktur busur pada bangunan aula bambu memiliki bentang $7 \mathrm{~m}$ dengan titik paling rendah berada pada ketinggian 1,5 meter di atas lantai kerja. Sifat bambu yang elastis dimaksimalkan dengan membuat struktur dengan bentuk lengkung. Satu batang bambu tali tidak mungkin digunakan untuk struktur busur dengan bentang 7 meter dan tinggi 6,5 meter. Oleh sebab itu, pada bangunan ini digunakan 3 batang bambu tali yang diikat sejajar untuk menghasilkan diameter yang lebih besar.

Sebagai struktur busur, batang busur atas menjadi penyalur beban utama karena bersinggungan dengan struktur atap pelana, sedangkan batang busur bagian bawah berperan sebagai penguat yang dihubungkan dengan sistem rangka batang. Struktur busur juga memiliki beban horizontal karena kecenderungan struktur busur untuk menjadi lurus juga dibebani. Selain itu, sifat bambu yang lentur membuat gaya horizontal tersebut muncul dari struktur bambu itu sendiri.

Pondasi yang digunakan pada bangunan ini adalah pondasi beton bertulang. Struktur bambu tidak masuk ke dalam pondasi beton, jika hal ini dilakukan, akan menyulitkan proses penggantian batang ketika bambu rusak. Batang bambu pada pondasi bangunan ini hanya duduk di atas pondasi pedestal beton. Dari dalam beton, terdapat tulangan baja yang keluar dari pondasi dan masuk ke dalam batang bambu. Batang bambu kemudian dilubang untuk memasukan cor beton ke dalam batang bambu yang dimasuki tulangan baja.

Kontak bambu dengan cor beton sering kali menimbulkan kekhawatiran bahwa bambu menjadi basah dan kehilangan kekuatannya. Menurut Effan Adhiwira, hal ini tidak terjadi karena selama proses konstruksi, bambu juga mengalami proses pengeringan bersamaan dengan keringnya cor beton di dalamnya. Ketika di lapangan, kondisi seperti hujan juga tidak dapat dihindarkan sehingga bambu memang akan basah. Basah pada bambu menjadi bermasalah ketika tidak dikeringkan karena akan membuat bambu membusuk.

Bambu sebagai material yang elastis akan memiliki gaya lenting ketika dilengkungkan. Pada bangunan ini, struktur busur terbuat dari tiga batang bambu tali yang sisi bawahnya diiris sehingga bambu kehilangan gaya lentingnya. Bambu tali yang melengkung pada bangunan ini sudah tidak memiliki gaya lenting sama sekali. Namun sebagai struktur busur, gaya lenting tersebut tetap ada jika struktur busur dibebani akibat bentuk busur itu sendiri.

Gaya horizontal yang berasal dari gaya lenting struktur busur juga berkurang karena radius lengkung batang atas besar sehingga sebelum menyentuh pondasi, struktur sudah cenderung lurus dan didominasi oleh gaya vertikal. Batang busur bawah dengan radius lengkung lebih kecil memiliki gaya horizontal yang lebih besar sehingga gaya horizontal tidak dapat terhindarkan pada struktur ini. Gaya tersebut diantisipasi dengan bentuk pondasi berupa buttress. 


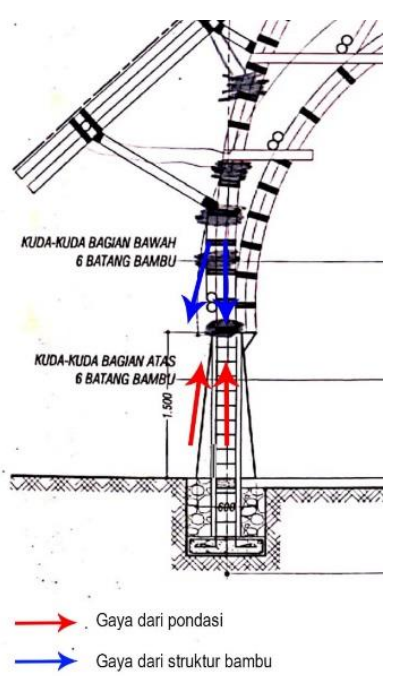

Gambar 11. Analisis gaya pada pondasi

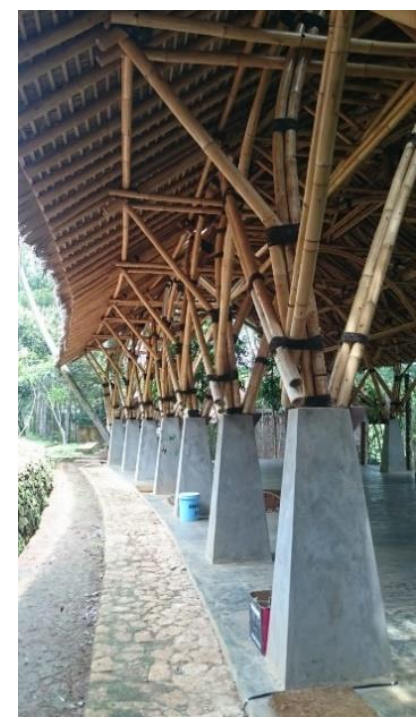

Gambar 12. Pondasi pada bangunan

Dalam struktur ini, batang horizontal berperan sebagai batang tarik dan batang diagonal sebagai batang tekan. Sedangkan batang busur atas mengalami gaya tekan dan batang busur bawah mengalami gaya tarik. Batang horizontal pada struktur ini selain untuk menjaga bentuk rangka batang, juga untuk menahan gaya horizontal dari bentuk busur.

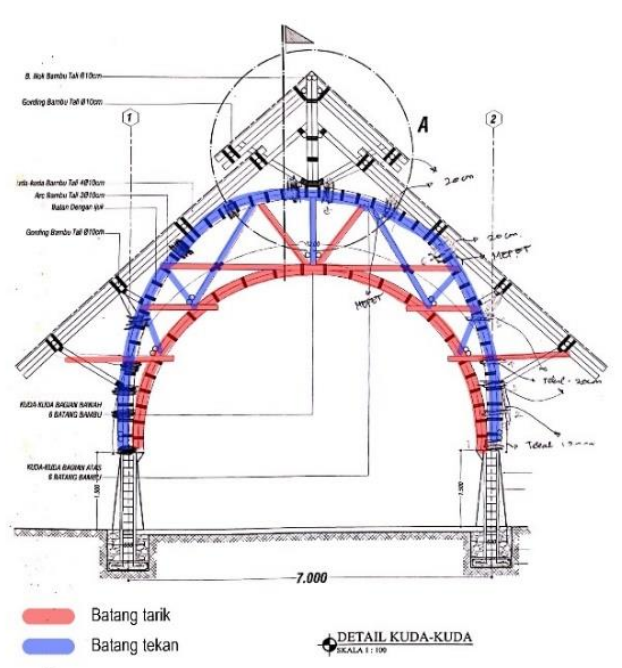

Gambar 13. Analisis gaya tarik dan tekan pada struktur busur

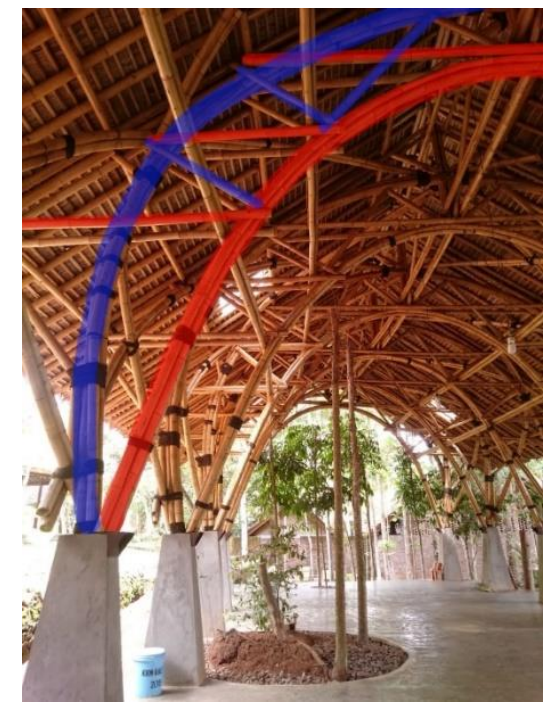

Gambar 14. Analisis gaya tarik dan tekan pada struktur busur

Seperti struktur pada umumnya, beban lateral menjadi pertimbangan dalam setiap desain struktur. Beban lateral pada struktur bangunan ini diantisipasi dengan dua cara. Pertama adalah dengan dengan bracing lengkung yang menghubungkan setiap struktur secara diagonal dan juga adanya balok horizontal yang menghubungkan struktur secara sejajar. Bracing diagonal menghubungkan empat struktur busur dengan titik awal dan titik akhir yang berseberangan. Bracing ini terbuat dari dua bambu tali yang diikat sejajar dan disambungkan dengan baut dan ikat ijuk pada struktur busur. 


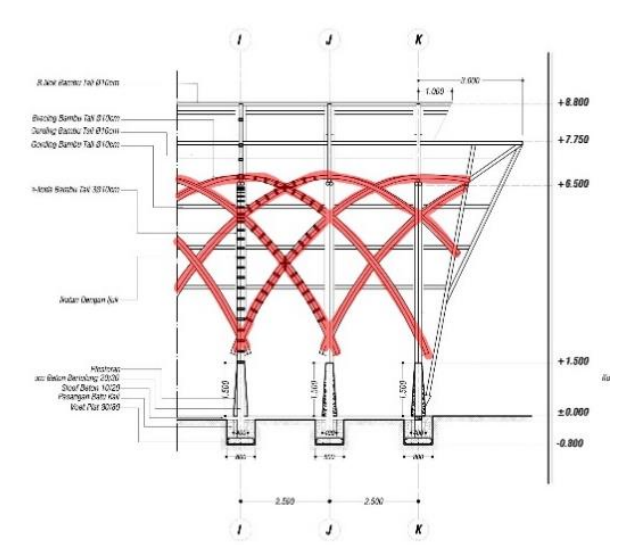

Gambar 15. Penggunaan bracing pada struktur bangunan

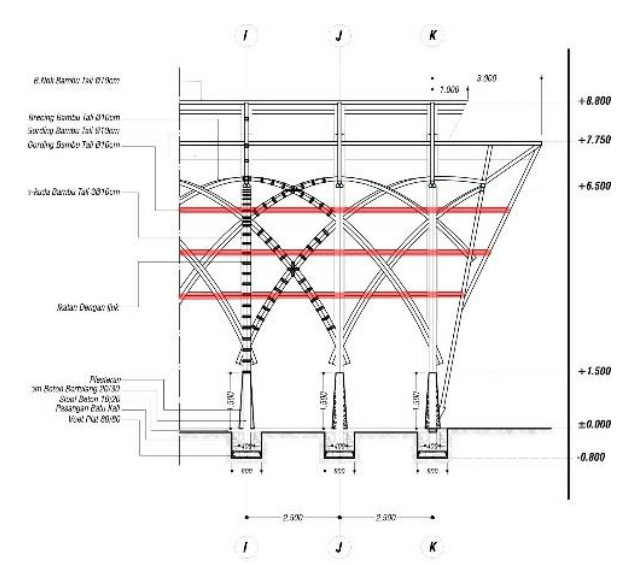

Gambar 16. Penggunaan batang balok yang mengikat antar struktur

Terdapat tiga jenis sambungan utama pada struktur bangunan ini. Setiap jenis sambungan digunakan berbeda-beda tergantung bentuk strukturnya. Sambungan yang pertama adalah sambungan baut dengan ikatan ijuk. Ikatan ini digunakan pada sambungan bracing dengan batang busur utama. Terdapat tiga poros pada sambungan ini, dua dari bracing dan satu dari struktur busur. Ketiga garis ini berada pada poros yang berbeda sehingga hanya saling bersinggungan. Sambungan ini bersifat jepit, sehingga gaya vertikal, horizontal, dan momen pada sambungan ini dapat teratasi.

Sambungan kedua adalah sambungan dengan baut. Sambungan ini berada pada struktur rangka batang yang menghubungkan kedua busur. Sambungan ini menghubungkan total lima batang bambu. tiga bambu dari struktur busur dan dua batang dari rangka batang yang menjepit struktur busur. Gaya momen pada sambungan ini tidak terlalu besar sehingga sambungan baut yang menahan gaya horizontal dan vertikal saja sudah cukup kuat.

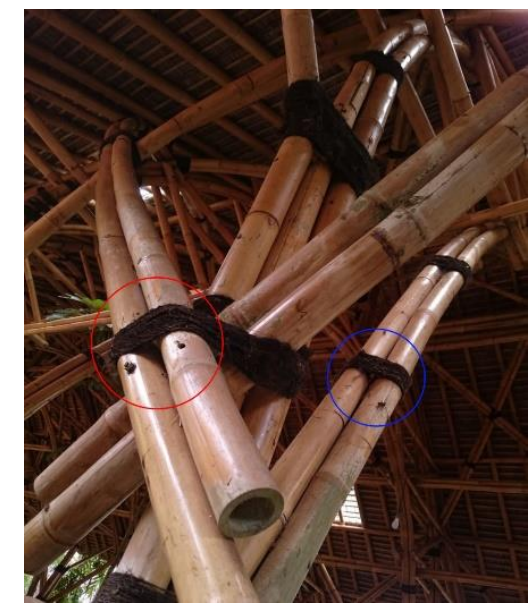

Gambar 15. Penggunaan bracing pada struktur bangunan

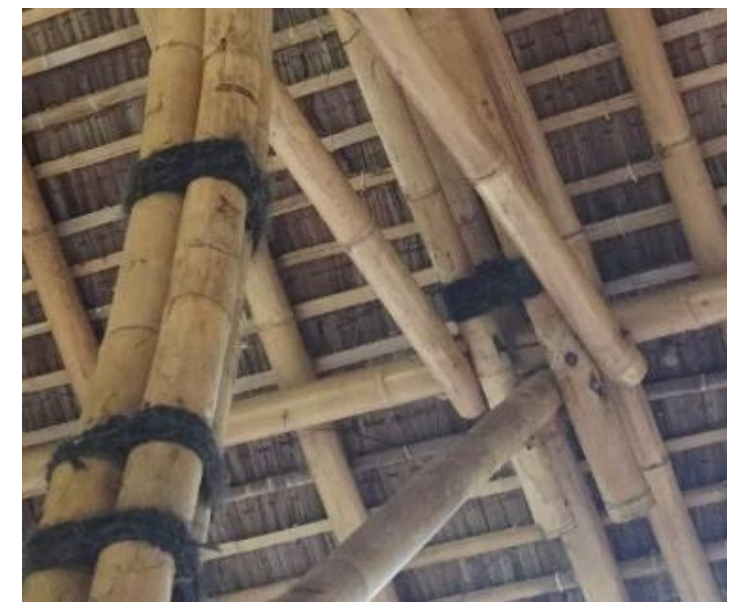

Gambar 16. Penggunaan batang balok yang mengikat antar struktur

Sambungan dengan baut juga digunakan pada sambungan sekur dengan kuda-kuda atap. Sambungan ini menghubungkan satu batang sekur yang dijepit oleh dua batang kudakuda. Sambungan yang juga terdapat pada struktur ini adalah sambungan yang mengikat tiga 
batang bambu pada struktur busur. Sambungan ini menggunakan pasak bambu dan diikat dengan ijuk. Sambungan ini mempertahankan ketiga batang bambu agar tidak saling terpisah.

Sambungan baut menjadi jenis sambungan yang dominan digunakan pada bangunan ini. Menurut Effan, sambungan baut dipilih karena sambungan baut lebih kuat dalam menahan beban geser karena sistem baut yang mengunci pada kedua sisi sedangkan sambungan pasak karena hanya satu titik, lebih rawan terhadap beban geser. Selain itu, nilai praktis juga menjadi alasan pemilihan sambungan baut.

Dalam bangunan dengan struktur bambu modern, penyaluran gaya menjadi lebih kompleks dibandingkan bangunan tradisional, oleh sebab itu diperlukan sistem sambungan yang kuat dan praktis. Walau sambungan baut dominan dipakai, perancang tetap menggunakan ikatan pasak dan ijuk pada beberapa bagian sebagai bentuk penerapan unsur lokalitas.

Pada bangunan ini, terdapat pecah dan retak pada beberapa bagian sambungan. Menurut Effan, hal ini disebabkan oleh human factor. Tukang yang mengerjakan bangunan ini adalah tukang lokal yang belum mengenal teknik konstruksi bambu. Selain itu, hal ini juga disebabkan karena bagian pangkal busur merupakan bagian yang menahan beban paling besar, sehingga perlu perlakuan khusus.

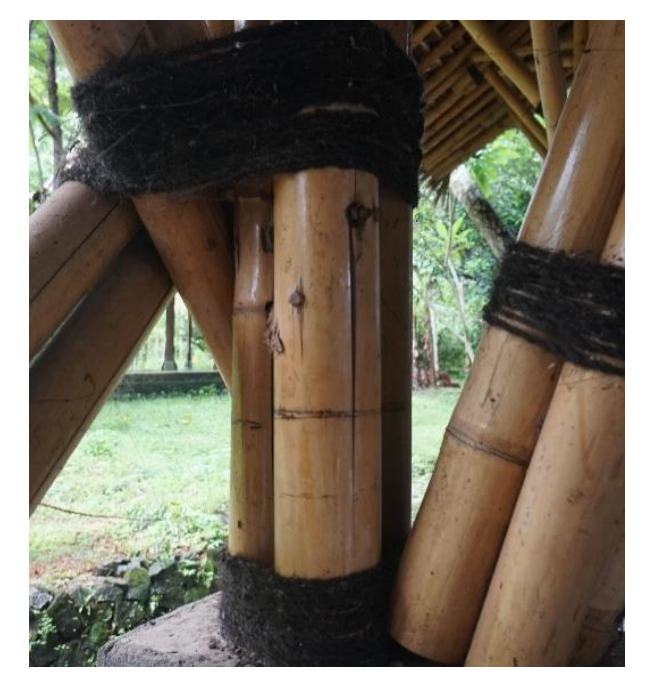

Gambar 15. Penggunaan bracing pada struktur bangunan

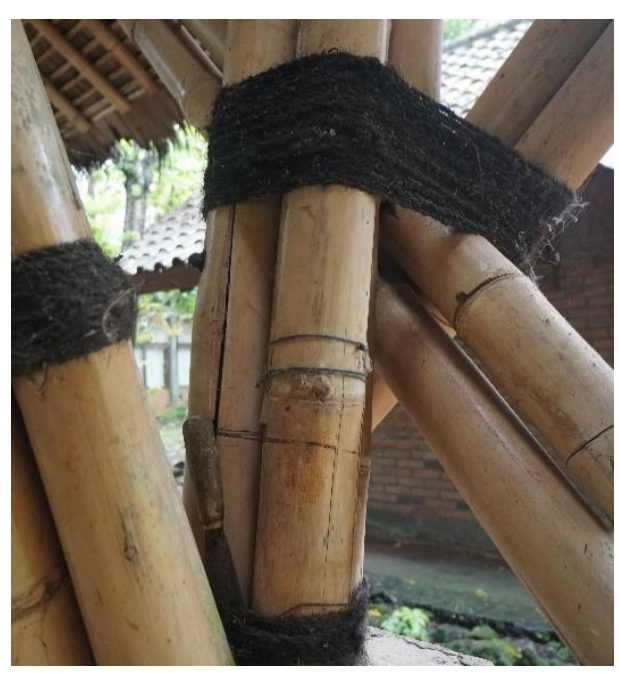

Gambar 16. Penggunaan batang balok yang mengikat antar struktur

Aula bambu di Bumi Pemuda Rahayu telah melewati dua kali renovasi mayor. Renovasi pertama dilakukan enam bulan setelah berdiri dengan mengganti atap genteng tanah liat menjadi atap rumbia. Atap genteng terlalu berat sehingga membuat struktur busur lendut. Ketika itu, struktur busur masih terdiri dari satu busur. Atap genteng tanah liat yang diganti dengan rumbia membuat beban atap lebih ringan.

Renovasi kedua dilakukan pada tahun 2018. Penambahan struktur busur menjadi dua busur dengan rangka batang dilakukan agar struktur lebih kuat dan secara desain terlihat lebih gagah. Pondasi pada awal bangunan dibangun tidak menyediakan ruang yang cukup untuk tempat dudukan struktur baru, oleh sebab itu ditambahkan plat siku baja yang dipasang pada struktur beton untuk menopang struktur busur baru.

Bambu yang sudah berdiri sebagai bangunan terkadang membutuhkan perawatan lanjut dengan mengoleskan zat kimia maupun non-kimia untuk menghindarkan dari rayap dan jamur, mengencangkan baut yang longgar, dan memeriksa kualitas bambu. Selain itu juga bisa digunakan cat eksterior anti air untung menjaga bambu tetap kering. Pada aula bambu Bumi Pemuda Rahayu, terakhir dilakukan perawatan adalah tahun 2018. 


\section{KESIMPULAN}

Bangunan aula bambu di Bumi Pemuda Rahayu telah memperhatikan kelestarian bambu sebagai material utama. Mulai dari tahap desain yang dimulai dari pemilihan material, pengawetan bambu, sampai upaya desain untuk menghindarkan bambu dari pengaruh luar.

Dalam tahap konstruksi, bangunan ini memenuhi konsep keberlanjutan material bambu. Pada tahap ini, ketepatan bentuk dan penggunaan material menjadi poin utama agar struktur yang terbentuk merupakan struktur yang tahan lama. Pemilihan sambungan juga tepat, hanya saja pada bagian pangkal struktur busur perlu ada perlakuan khusus karena menerima beban paling besar.

Kekurangan bangunan ini adalah penerapan konsep keberlanjutan material bambu pada tahap renovasi. Beberapa bagian struktur sulit jika harus diganti, hal paling mungkin dilakukan adalah dengan menambah perkuatan struktur pada bagian tersebut. Walau begitu, renovasi akan dilakukan jika terjadi kerusakan, hal ini yang diantisipasi melalui tahap-tahap sebelumnya dengan memaksimalkan usia bambu.

Bangunan ini akan lebih lengkap dalam menerapkan konsep keberlanjutan material bambu jika saja dapat menggunakan material yang diekstraksi dari sekitar tapak. Selain mengurangi proses distribusi material, penyediaan material untuk renovasi juga akan lebih terjamin karena ekstraksi sudah pernah dilakukan sebelumnya. Selain itu, instalasi sambungan baut juga dapat diperhatikan lagi agar tidak terjadi retak dan pecah pada bambu karena dapat mengurangi kekuatan bambu. Pada bagian pangkal busur, dapat digunakan detail sambungan dengan pipa aluminium untuk mencegah pecah pada serat bambu.

Hal yang paling sulit dilakukan pada bangunan ini adalah proses renovasi ketika diperlukan. Akan lebih baik jika sistem dan bentuk struktur memungkinkan semua bagian dapat diganti jika suatu saat diperlukan. Sistem struktur knock-down bisa menjadi alternatif pilihan desain. Walau usia bambu yang dapat bertahan bahkan sampai puluhan tahun, hal tersebut ada baiknya tetap diperhatikan.

\section{DAFTAR PUSTAKA}

BERGE, B. (2009). The Ecology of Building Materials Second Edition. Oxford: Elsevier.

CHING, F. D. (2014). Building Structures Illustrated Pattern, Systems, and Design: Second Edition. Canada: John Wiley \& Sons.

DUNKELBERG, K. (1985). IL 31: Bambus Bamboo: Bamboo as a Building Material. Stuttgart: Karl Kramer Verlag.

FRICK, H. (2004). Ilmu Konstruksi Bangunan Bambu. Yogyakarta: Kanisius.

FRICK, H. (2007). Sistem Bentuk Struktur Bangunan. Yogyakarta: Kanisius.

JANSEN, J. J. (2000). Designing and Building with Bamboo. Eindhoven: Technical University of Eindhoven.

MCLENNAN, J. F. (2004). The Philosophy of Sustainable Design. Canada: Ecotone Publishing Company LLC.

MINKE, g. (2012). Building with Bamboo. Basel: Birkhauser.

NETWORK, C. A. (2013). Bamboo Construction Source Book.

PERMANA, I. (2017). Sifat Fisika dan Mekanika Bambu Apus (Studi Kasus: Bambu Daerah Turgo). Yogyakarta: S1 Teknik Sipil UGM.

PERMANA, I. (2017). Sifat Fisika dan Mekanika Bambu Apus (Studi Kasus: Bambu Daerah Turgo). Skripsi Fakultas Teknik Program Studi Teknik Sipil UGM.

SCHODEK, L. D. (2014). Structures. New Jersey: Pearson Education.

SCHUELLER, W. (1996). The Design of Building Structures. New Jersey: Prentice-Hall, Inc.

SULISTYOWATI, A. (1997). Pengawetan Bambu. Wacana VI. 
SURIANI, E. (2017). Bambu Sebagai Alternatif Penerapan Material Ekologis: Potensi dan Tantangannya. EMARA Indonesian Journal of Architecture Vol. 31 No. 1, 41.

SUTANTO, H. (2003). Struktur \& Konstruksi Bentang Besar.

SYAHRIYAH, D. R. (2016). Penerapan Aspek Green Material pada Kriteria Bangunan Ramah Lingkungan di Indonesia. in Prosiding Temu Ilmiah IPLBI.

UMAR, U. A. (2014). Sustainable Building Material for Green Building Construction, Conservation and Refurbishing. In Management in Construction Research Association (MiCRA).

YORESTA, F. S. (2013). Sifat Mekanisme Bambu Betung. Jurnal Hutan Tropis Volume 1 No. 3. 